\title{
Disillusionment and the dilemma of 'the Democratic Type': From Plato (Athenian populism), to Helen Zille (constitutional democracy), Cyril Ramaphosa (cooperative democracy) and Jesus Christ (compassionate democracy)
}

Author:

Daniël J. Louw ${ }^{1}$ (D)

Affiliation:

${ }^{1}$ Department of Practical Theology, North-West

University, Potchefstroom,

South Africa

Corresponding author:

Daniël Louw,

djl@sun.ac.za

Dates:

Received: 03 July 2019

Accepted: 10 Oct. 2019

Published: 27 Feb. 2020

How to cite this article:

Louw, D.J., 2020,

'Disillusionment and the

dilemma of 'the Democratic

Type': From Plato (Athenian populism), to Helen Zille

(constitutional democracy),

Cyril Ramaphosa (cooperative democracy) and Jesus Christ (compassionate democracy)' In die Skriflig 54(1), a2516. https://doi.org/10.4102/ids. v54i1.2516

\section{Copyright:}

C) 2020. The Authors. Licensee: AOSIS. This work

is licensed under the

Creative Commons

Attribution License.

Read online:

Scan this QR code with you smart phone or mobile device to read online.
Worldwide democratic institutions are threatened by right-wing reactions. The fear for a loss of power brings about a paradigm shift from democratic sensitivity to autocratic control. Political leaders tend to become more reactionist, populistic and despotic. Conservative reactions hamper processes of democratisation. Besides the migrant crisis, democracy in South Africa staggers under escalating forms of state capture, fraud, violence, mismanagement and undisciplined social behaviour. Plato's exposition of the 'democratic type' and his criticism of Athenian populism are used to reveal possible weaknesses in our current democratic dispensation. Within the political arena, voices for a new and fresh approach to processes of democratisation is assessed and discussed. Thus, the reference to a plea for constitutional democracy (Helen Zille), and cooperative democracy that should include radical attitudinal change (Cyril Ramaphosa). It is argued that an anthropology, based on the passio Dei, can provide a spiritual basis for a new ethos and thus contribute to the establishment of a compassionate habitus of caring. In this regard, practical theology should focus on an ecclesial presence that is 'redemptively pervasive' and directed by the bowel categories of ta splanchna.

Keywords: Democratic type; Compassionate type; Constitutional democracy; Commonwealth democracy; Theology of the intestines; passio Dei; Practical theology.

\section{Introduction}

Disillusionment, sheer disillusionment - this is more or less how one can summarise humankind's response to the 'dream of democracy' in the first two decades of the 21st century. It seems as if the ideology of democracy, with its zeal for establishing a free and fair society within the contours of global networking, is stirring up tension and disillusionment in many developing countries such as South Africa. The ideal of a humane society, based on justice, equality and freedom for all, seems to have become in many cases a shattered dream: a fading fata morgana.

In a very recent article, the political analyst, Professor Amanda Gouws (2019:10), aptly remarks that one becomes aware of a growing global dissatisfaction regarding processes of democratisation and the autocratic stance of governments. It seems that, due to a growing dissatisfaction, governments respond in a more autocratic way. The fear for a loss of power brings about a shift from democratic sensitivity to autocratic control. Prof. Gouws (2010:10) refers to the fact that ordinary people become 'streetwise' and turn to protest campaigns. She refers to protest marches in Hong Kong demonstrating against the autocratic stance of the Chinese government, demonstrations in Egypt against the military regime, and demonstrations in South Africa against violence and abuse of women. In 2016, there were 7011 protest demonstrations in Mexico City, 5000 in Berlin, 1983 in Madrid, 1500 in Den Haag, and 2383 in Paris (Gouws 2019:10). Citizens are convinced that their democratic voice is not heard anymore. In turn, political leaders become more reactionist, populistic and despotic, for example Donald Trump and Boris Johnson (Gouws 2019:10).

Without any doubt, the pillars of the democratic ideal, namely freedom, human rights, justice and human dignity are becoming unstable and indeed critical. In an article 'World identity crisis', Ian Bremmer (2019b:29-33) points out how the optimism regarding a somewhat global democratic alliance between leading nations, is busy to fade away. For example, the predicament of Canada's Prime Minister, Justin Trudeau, regarding his liberal viewpoints, seems to isolate him even from 
New York: A global order shows every sign of moving away from him (Bremmer 2019b:30). Bremmer (2019b) further mentions that:

Trudeau's optimism has helped make him one of the few remaining advocates on the world stage for the global world order that seemed so certain until recently. He remains an unapologetic supporter of free trade, immigration, diversity, human rights - all the causes that have been challenged by nationalist populism elsewhere, including south of the world's longest undefended border. (p. 31)

According to the research of Gouws (2019:10), global demonstrations worldwide reveal that young people are tired for the corruption of elite politicians, unemployment and the lack of a dignified life. It is as if the comfort zone of private, individualised prosperity and 'the fear for the other' as intruder and foreigner, brought about a conservative backlash and selfish defensive mode with the following praxis: We have to defend our own territory over against the threat of the displaced other. The otherness of the other has become a source of anxiety and constitutes a web of social xenophobia and backlash of isolating exclusiveness. Our own happiness, based on the urge for need-satisfaction (the hedonic treadmill of wanting), constitute a network of endless desirables that must serve our own private success. Unfortunately, within impoverished societies and large-scale settings of unemployed people, the desirables cannot materialise which is thus the reason for frustration and disillusionment.

According to Salman Rushdie in his novel Quichotte (2019:23), disillusionment is connected to the fact that we live in a world where social media could be hacked, democracy is corruptible and American populism is bullying the global village (2019:28). Thus, the following dilemma: "'So then, quit!" said the wicked angel on his left shoulder. "Nobody cares but you"' (Rushdie 2019:29). While facing the reality of corruption, fraud and destructive populism, should we quit or turn to a caring engagement in order to foster a kind of 'compassionate democracy' in South Africa?

The point is that the democratic ideal of freedom, justice, equality and human rights does not necessarily guarantee human dignity and significance. Thus, the core question of the article is the following: What is 'the more' that is needed to supplement and direct democratic initiatives? How important is attitudinal change in political incentives to materialise the democratic ideal of a humane and just society?

The dilemma of a very individualistic privatisation of democracy directed by the global projection of the more Northern American version of liberty (democracy as a vehicle for personal freedom, individual need-satisfaction and the projection of an affluent society) is causing political unrest and dissatisfaction. This dilemma is summed up in the following quotation by Ian Bremmer (2019a):

Nearly three decades after the Cold War's end, it's no longer clear that American-style liberal democracy has carried the day. $\mathrm{Xi}$ Jinping has consolidated power in China on a scale not seen since Mao. Vladimir Putin has served longer than any other Russian leader since Stalin. Even many democracies are being undermined by populism. (p. 17)

Bruce H. Dolph (2019:2), in a letter to Time, refers to an old Irish priest who had been working in the outskirts of Nairobi for 40 years. The priest's reaction to the American version within a poor African setting was 'Let me tell you something: Democracy doesn't work for everybody, and you Americans should stop trying to push it down people's throats.'

Within the transition from a kind of 'State Captured Democracy' under President Jacob Zuma to the new dream of a 'Smart City Democracy' for South Africa under the leadership of President Cyril Ramaphosa (2019b), the following research question emerges: What are the shortcomings and possible potholes in liberal democracy? What are the factors contributing to a rather global disillusionment and scepticism regarding the success rate of democracy within a developing country such as South Africa? What are the challenges within the application of democracy within the contexts of the current discourse on state capture, corruption, fraud, violence and severe poverty? What is the 'missing link' after the Mandela dream of a democratic South African society seems to fade away? What are the 'weak points' in a very individualised interpretation of democracy? How do values emanate from a global market driven economy, the pursuit of happiness and the demands for personal need-satisfaction impact on local aspiration for a new democratic dispensation?

My research assumption and presupposition are that Plato's exposition on the failure of the 'democratic type', can help us to understand the shortcomings of contemporary versions of liberating democracies, as well as the phenomenon of disillusionment under many people living on the brink of poverty. Plato linked his criticism to his conviction that without wisdom and sound basic virtues, inner discipline and attitudinal change (change of habitus), politics is delivered out to the unsophisticated needs of sheer Athenian populism.

I decided to compare Plato's criticism on the politics of Athens with critical viewpoints on democracy in South Africa.

To my mind, the former leader of the Democratic Alliance, Helen Zille, represents a rather 'constitutional democracy' as promoted by the notion of rule of law, protected rights and freedoms for all individuals irrespective of racial and gender differentiation, free and fair elections, and accountability and transparency of government officials. Citizens have a responsibility to uphold and support these principles, and should maintain their rights by means of democratic institutions and not through destructive protests.

In contrast with the era under President Zuma, the new President, Cyril Ramaphosa, represents a kind of 'cooperative democracy', that tries to bring about a somewhat unifying perspective within the dynamics of cultural diversity. 
His attempt to create a new sense of togetherness among the citizens of South Africa, to establish a new kind of 'commonwealth of empathetic coexistence', is a challenge to all South Africans. It is a plea for attitudinal change in order to provide a moral basis for the re-establishment of a democratic dispensation.

Speaking at the launch of the first Transport Month held near the busy N3 in Heidelberg on 05 October 2019, President Cyril Ramaphosa (2019a) said: 'Our roads won't become safer unless we change our attitudes as road users.' The notion of attitudinal change in order to enhance the space of safety, mutual respect and human dignity within the sphere of civil society, has been applied to one of the pillars of a fair and just democratic dispensation, namely the disposition of citizens.

One of the most intoxicated spaces is the human heart when it is infiltrated by hate and suspicion. The current case of 'hate speech' against the rugby player Eben Etzebeth reveals the current racial polarisation between white and black people in South Africa. On 13 December 2018, during a live interview on Radio 702 and Cape Talk Radio FM by Xolani Gwala, President Cyril Ramaphosa made the following very alarming remark: 'White South Africans, mainly those with power in their hands, must realise that particularly young black people are becoming increasingly angry about their "lackadaisical" attitude' (Ramaphosa 2018).

One can conclude and say that the realm for change in order to restore confidence in our very young but frail democracy resides in the hearts of citizens. Thus, the plea for attitudinal change. Democratisation is not merely about constitutional and ideological changes. It desperately needs a habitational change and reformation of intention.

It is my very basic contention that a theological stance to life issues, very specifically within the disciplines of practical theology and pastoral caregiving, should be reformulated in terms of a praxis approach that focus on 'habitus'. Already in 1983, the practical theologian, Edward Fairley, advocated for a practical theology of habitus. If theology tends to be practical and to be engaged within the praxis of life events and the social affairs of civil society, it should focus of the realm of attitudes. 'Theologia practica is simply the habitus viewed to its end.' Fairley's approach is based on the argument that practice means that aspect of the habitus or wisdom, in which the divine object sets requirements of obedience and life. 'Both reside in the single existential habitus called theology. Theory/practice is based here on what could be called a phenomenology of theology as a habitus' (Fairley 1983:27). Habitus is in this sense a spiritual category and viewed in the Middle Ages as a power and act of 'the soul itself' (Fairley 1983:23). Ecclesial presence and ministry thus mean contributing to the normative dimension of life and a 'world-transforming aspect' (Fairley 1983:39).

It is argued that a sound understanding of different modes of democratic ideals can help communities of faith and different church denominations to revisit their ecclesial paradigms in order to become engaged in, what I want to call, the beautification of civil life in South Africa.

The philosopher, Peter Singer (2015:vii), is convinced that 'the more' that is needed to transform current interpretations and manifestations of democratic philanthropy, is an ethical stance. Singer (2015:vii) calls this approach 'effective altruism':

Living a minimally acceptable ethical life involves using a substantial part of our spare resources to make the world a better place. Living a fully ethical life involves doing the most good we can.

But is 'effective altruism' enough? Should an ethical-based democracy not be supplemented by a spiritual approach, namely the aesthetics of compassion and the ethos of diaconic outreach to people in their need? What is the contribution of a Christian spirituality of compassion in this regard?

The following practical theological and pastoral challenge will be addressed: How should the church respond to the weakness of the 'democratic type' (Plato 1946:276)? With a 'practical theological approach' is then meant probing into the attitude of people and the undergirding motivation and intention (telos) for a praxis approach to change and the healing of our society (Louw 2016:91-182). A praxis approach should be steered by the pastoral notion of compassionate being-with as determined in Christian theology by the passio Dei (Louw 2016:271-380). With reference to anthropology in Christian reflection, the question is: What contribution can an exposition on the anthropological character of the 'Christian type' make to the debate regarding the fostering of a 'democratic type' that can penetrate the disillusionments of many on grass roots level? How can ethics be supplemented by a spiritual approach to processes of democratisation?

\section{Probing the 'pursuit of happiness' and its global connection with liberal democracy and signs of disillusionment}

Derren Brown, in his publication on 'Happiness' (2017:67), remarks as follows on a global emphasis on personal needsatisfaction within undertones of constant unhappiness: 'America's obsession with positive thinking, and therefore the fetishising of desire, has only exacerbated this potential for modern unhappiness.' Happiness means to maintain our own comfort zone. Taleb (2013:55) calls this craze for comfort 'a disease of civilization: make life longer and stronger (flourishing), while people are more fragile and more sick'.

Yuval Noah Harari (2016) calls this craving for more comfort, strength, happiness and control the upgrading of Homo sapiens into Homo deus:

We want the ability to re-engineer our bodies and minds in order, above all, to escape old age, death and misery, but once we have it, who knows what else we might do with such ability? So, we 
may well think of the new human agenda as consisting really of only one project (with many branches): attaining divinity. (p. 46)

In this attempt to attain divinity, the democratisation of life becomes a major tool and ally to attain 'global happiness for all'.

Unhappiness and disillusionment even entered the political scenario in the USA. The USA is not really united anymore in terms of democratic values and the ideal of liberty for all. Donald Trump's policy of 'making America great again', infiltrated the very pillars of democracy. If refugees from Mexico are not welcome in the USA, how sustainable is the Northern American version of democracy?

The migration crisis and predicament of human displacement put anew the democratic ideal of liberalism under huge pressure

According to Abramson, Berenson and Walcott (2019:21), democracy is threatened by right-wing terrorism. The latter is becoming a global problem, resulting in devastating attacks from New Zealand to Norway and contributing to a kind of global disillusionment. 'But it is particularly dangerous in the U.S., which has more guns per capita than anywhere else in the world ...' (Abramson et al. 2019:21).

The midterm election in 2018 revealed the tension between the exclusive conservatism of the Republicans, and the liberation ideology of the Democrats. Ball (2018:22) explains:

Now, for the first time in the Trump presidency, those two sides will square off in a divided government: Voters elevated House Democrats to serve as check on a scandal-plagued President and his party.

Disillusionment even penetrated the dream of a united European Union. The 'Brexit Fiasco' (Coe 2019:30-32) illustrates the disillusionment that democracy could guarantee a rather inter-European and prosperous European 'common-wealth'. Underneath the rather artificial optimism of Britain in the Olympic Stadion at the opening ceremony (July 2012), lurked a deep-seated anxiety. An anxiety about national prosperity and the threat of immigration (Coe 2019):

Brexit is a lesson in how quickly a country can degenerate into division and factionalism, and how tenuous are the bonds that hold us together around the vexed issue of national identity. (p. 32)

The Brexit referendum was based on the pillars of democracy. However, democracy plunged the United Kingdom into anarchy (Brown 2019:34). Brexit is revealing disillusionment it underlines 'the impoverishment of a shrinking nation in the cause of a mirage of sausage-and-mash "sovereignty" (Brown 2019:34).

According to the Polish sociologist and philosopher, Zygmunt Bauman, the global refugee crisis reveals the arrogance of Western democratic ideology. He (Bauman
2016:123-124) calls the political strategy for a homogenous inclusive and integrated democratic society an aggressive mode of masked enculturation and social assimilation. For Bauman (2016:122) this policy is 'a typical Western approach'; it boils to a radical offensive strategy. The polarities of integration - segregation oscillates between the division of we and them, ${ }^{1}$ it flourishes on an emotional turmoil and the tension between incompatible polarities: foreclosure (Abschottung) and integration.

The current displacement dilemma of homeless people is indeed ambivalent and has the capacity to end in a moral debacle - a somewhat apathetic indifferentism regarding the tragedy and the desperate cry of suffering, vulnerable people.

It has now become 'common talk' in a way: Archbishop Desmond Tutu's dream of a unifying 'rainbow nation' (unity in diversity) seems to become a nightmare of disillusionment. In a very recent article in Time (Baker 2019:34-41), South Africa has been described as a catastrophe of division, rather than an example of democratic unification. The article refers to a community organiser, Kenny Tokwe, who has been living in ImizamoYethu (Hout Bay, Cape Town). Tokwe pointed out that South Africa is still a country of two nations: the rich white people and the poor black people. Despite the fact of 25 years since South Africa's first multi-racial democratic elections, held on 27 April 1994, the dream of Mandela is shattered, because democracy did not bring an end to the institutionalised racial segregation of the apartheid regime (Baker 2019:36). Instead of equality, inequality is still existent within the framework of escalating violence, crime and corruption.

If the democratisation of life and the craving for more are indeed an indication of the features of life in the global village, how should communities of faith, especially the Christian community and the church respond to these challenges? However, if processes of democratisation and the divinisation of Homo sapiens do not deliver the goods and plunge our being human again into dehumanising disillusionment, what can a Christian view of life offer in our quest for human dignity? As Plato aptly pointed out, the establishment of justice goes hand in glove with the question of human dignity (Piechowiak 2019:17-18). 'The dignity of a person -as the source of all human rights - is a fundamental value found across legal systems' (Piechowiak 2019:18).

\section{Plato: the obstacle of 'the democratic type' - A threat to 'mutual friendship' and harmony}

For Plato, wisdom and the striving towards the 'vision of goodness' are more fundamental than merely the democratic plight for human rights. Goodness is the highest object of knowledge (Plato 1946:228). Plato (1946) therefore reminds his friends of the fact that the law is not concerned:

1.'Wir müssen die Kunst der Integration ganz neu lernen, unter Verzicht auf das Entweder-oder, wenn wir unserer Lage gerecht werden sollen' (Bauman 2016:124). 
[T] o make one class specially happy, but to ensure the welfare of the commonwealth as a whole. By persuasion or constraint it will unite the citizens in harmony, making them share whatever benefits each class can contribute to the common good; and its purpose in forming men of that spirit was not that each should be left to go his own way, but that they should be instrumental in binding the community into one. (pp. 228-229)

This emphasis on 'community wholeness' was, for Plato, based on the greatest possible mutual friendship (Piechowiak 2019:25). It points to what Plato called the supreme philosophical disposition, namely 'gentleness'. 'A proper training would produce courage; but if that element is overstrained, it naturally becomes hard and savage. Gentleness, on the other hand, is characteristic of the philosophical disposition' (Plato 1946:98).

For Plato (1946:118-126), the praxis of true wisdom is linked to the following qualities that should be reflected in the governance of a state: prudent counselling, courage - the power of preserving in all circumstances, temperance - a kind of orderliness and self-control, and justice - right behaviour as directed by the principle that 'neither party shall have what belongs to another or be deprived of what is his one' (Plato 1946:125). Justice should thus never degenerate into 'a form of skill in cheating, provided it be to help a friend or harm an enemy' (Plato 1946:11).

To promote friendship is to do well (Singer 2015:23-74) to an honest person; enemies can only be harmed when they are wicked - the unjust (Plato 1946:13). 'Then only the just man is happy; injustice will involve unhappiness' (Plato 1946:38). In a nutshell, justice together with all the other virtues, are geared to address the quest for human dignity: 'the improvement of a man, about becoming good' (Piechowiak 2019:69).

The surprising fact is that Plato linked justice and ethics to the basic notion of aesthetics (living well and well-being): the beauty of orderliness, harmony and bestowing grace. Soulfulness, and therefore the whole life of human beings, stands in need of rhythm and harmony. When spiritual excellence is combined with bodily beauty in a living person, it constitutes proper love (eros) (Plato 1946:86). Without harmony and justice, life becomes chaotic (Plato 1946):

And the absence of grace, rhythm, harmony is nearly allied to baseness of thought and expression and baseness of character; whereas their presence goes with that moral excellence and selfmastery of which they are the embodiment. (p. 87)

The previous outline, regarding what one can call the aesthetics and poetry of life, helps one to understand why Plato questioned the contribution of democracy to the instalment of a commonwealth of good and beauty within the realm of Athenian politics. The core problem with 'the democratic type' - the democratic man - is the difficulty to control the realm of desires. In the long run, the pleasures of the moment gain the upper hand over the democratic temperament based on the principle of freedom and equal rights for all (Plato
1946:274). Perhaps then the reason why an oligarchy, that is, the striving to become as rich as possible, cannot direct the transition to democracy. 'We can see that at once that a society cannot hold wealth and honour and at the same time establish a proper self-control in its citizens' (Plato 1946:274).

The democratic type of man is in fact the product of oligarchy wherein the striving to become as rich as possible, leads to neglect, namely to curb riotous living and attend to poverty. Neglect leads to revolution (Plato 1946):

And when the poor win, the result is a democracy. They kill some of the opposite party, banish others, and grant the rest an equal share in civil rights and government, official being usually appointed by lot. (p. 276)

Plato describes the character of the 'democratic type of man' as follows:

- Freedom without inner discipline, because 'All are free'. Liberty and free speech are rife everywhere; 'anyone is allowed to do what he likes' (Plato 1946:276).

- Every person arranges his or her own manner of life to suit his or her personal pleasure. The result is the diversity and variety of individuals:

A democracy is so free that it contains as a sample of every kind; and perhaps anyone who intends to found a state, as we have been doing, ought first to visit this emporium of constitutions and choose the model he likes best. (Plato 1946:276)

- Authority becomes an irrelevant option. No one is obliged to be in authority however competent the person is. Nobody needs to submit to authority if you do not like it. The implication is that one responds to the dynamics of like - dislike. 'A wonderfully pleasant life, surely, for the moment' (Plato 1946:276).

- Instead of self-control, tolerance sets in:

In a democracy you must have seen how men condemned to death or exile stay on and go about in public, and no one takes any more notice than he would of a spirit that walked invisible. There is so much tolerance and superiority to petty considerations; such a contempt for all those fine principles we laid down in founding our commonwealth. (Plato 1946:276-277)

Thus, the following dilemma that contributes to sheer disillusionment:

A democracy tramples all such notions under foot; with a magnificent indifference to the sort of life a man has led before he enters politics, it will promote to honour anyone who merely calls himself the people's friend. (Plato 1946:277)

Therefore, the dilemma of the democratic type feeds the brutality of populism. Knowledge and right principles make place for basic appetites and needs of people (Plato 1946):

$[M]$ odesty and self-control, dishonoured and insulted as the weakness of an unmanly fool, are thrust out into exile; and the whole crew of unprofitable desires take a hand in banishing moderation and frugality, which means, as they will have it, are nothing but churlish meanness. (p. 279) 
To sum up: The predicament and dilemma of the democratic type is that they are directed by immediate appetite (surviving desires). This is without changing a disposition of having (consuming) and wanting into the wise disposition of gentleness, simplicity, self-control, inner discipline, responsibility for self and the other, sharing and just evaluation (prudence). Instead of the philosophical position of wisdom, the following destroying and harmful vices set in (Plato 1946):

Insolence, Anarchy, Waste, and Impudence, those resplendent divinities crowned with garlands, whose praises they sing under flattering names: Insolence they call good breeding, Anarchy freedom, Waste magnificence, and Impudence a manly spirit. (p. 279)

Although the social and political as well as cultural setting of Plato differed from our postmodern context, the similarities with the contemporary disillusionment with the outcome of the democratic slogan, 'liberty and equality', become quite evident. In fact, the following summary of Plato of the democratic type sums up the current dilemma of many in South Africa: 'His life (democratic type) is subject to no order or restraint, and he has no wish to change an existence which he calls pleasant, free, and happy' (Plato 1946:280).

The comparison between the weakness of democracy in the state of Athene and the current criticism on the government's response to the weaknesses in the South African version of democracy becomes evident. The current turmoil in South Africa and the many cases before the Zondo commission, reveal a quite similar setting. Our very young democracy is staggering under the same threat: subject to no order or restraint.

Kenny Tokwe (in Corruption Watch 2018), who has been living in ImizamoYethu (Hout Bay, Cape Town), claims as follows: People are torn apart (the neo-racism of white-black polarisation based on disillusionment). The democratised have cling to pleasure (wealth) - whether black or white and do not want to share; the impoverished have-nots do not benefit from the advantages of the new dispensation. In the meantime, the Zondo commission is revealing new fraud cases of insolence, anarchy, waste and impudence on a weekly base (Corruption Watch 2018).

If the 'democratic type' live with the slogan, 'All is free' and need satisfaction (personal appetite) becomes the norm, it becomes clear that democracy needs a state founded on an external judicial framework: Law, order and a constitution. What is most needed is a new discovery of a moral framework for civil society as directed by sound values and virtues such as respect, honesty, integrity, personal discipline and dutiful responsibility. The liberation ideology needs a sound judicial structure. Without the framework of a constitution, the public of 'civil society' becomes chaotic. The public order and law of 'Athens' must temper the needs of the 'democratic type'.

\section{Helen Zille: 'Constitutional democracy' and the obstacle of a culture of irresponsibility - Democracy within the 'intensive care' of South African politics}

Plato (2015) argued that democracy implies concern for the quality of the public life of the people of Athens. The Greeks were very sensitive to the danger of a retreat into the privacy of personal appetite (the lower drives). Politics and democracy cannot be exercised in the privacy of homes. Democracy is a social phenomenon linked to the safeguarding of the rights of the people. An individual who retreated from politics and public life was called an idiotes - a person who lacks the knowledge and social skills that mature individuals can be expected to possess. To avoid the position of idiotic withdrawal in South Africa, the pillars of constitutional democracy should be restored.

In South Africa, the 1994 elections are rendered as a milestone in the process of liberation. For the African National Congress (ANC) election means power, government rule and victory. It spells out the formal and legal end of the cruel apartheid regime.

During the time of apartheid and the Afrikaner establishment (promoted and safeguarded by the ruling National Party), the liberation option was kept alive in parliament by politicians from the so-called liberal left. For Helen Susman was a symbol of the liberal ideal of freedom for all. Largely, this ideal became the motor that drove the engine of the Democratic Party. In the new dispensation, the Democratic Alliance represented this ideal in its more Western mode. One of its courageous and intellectual representatives was Helen Zille.

In her speech on the 6th of June 2019 before the F.W. de KlerkStigting, Zille revealed a kind of disillusionment regarding the development of democracy in South Africa. With the title, 'Quo Vadis?' (Zille 2019:1), the impression was left that democracy in South Africa is on the brink of a terminal situation and thus currently hospitalised in the 'intensive care' of politics.

According to Helen Zille, the current disillusionment can be linked to the misconception that elections in a democratic dispensation is proof of a functional democracy. 'It is a common error that elections are sufficient evidence of a functional democracy' (Zille 2019:1).

Larry Diamond, the Stanford scholar known as Mr. Democracy, in his book Ill winds, pointed out that democracy is on the decline across the globe (in Vick 2019:52). The constituency for illiberal right-of-centre populism is threatening liberal democracy all over the globe. He argues that democracy entails more than elections. The challenge to democracy is to reinforce income security, to compete with globalised economy and the mobility of a migrating world. In this 
regard, an autocratic approach or attempt to move to an authoritarian regime cannot deliver appropriate goods to enhance a sense of democratic enthusiasm. In the meantime, Facebook perpetuates outrage and contributes to widespread disillusionment. When neo-fascism conquers democracy with the aid of right-of-centre populism, the pillars of democracy become threatened (Diamond in Vick 2019).

According to Helen Zille, democratic pragmatism and effectivity need a functional state mechanism in order to link the voice and needs of the people to their democratic aspirations (Zille 2019):

The essence of constitutional democracy is not winning and exercising power. It is the effectiveness of the institutions and conventions that ensure checks and balances on the abuse of power; and the notion that the State defends the rights and serves the people, not the ruling clique of the ruling party. (p. 1)

Zille refers to Francis Fukuyama, a political scientist from Stanford University, who said that a stable democracy with widespread prosperity requires three distinctive national attributes: respect for the law, a capable state, and a culture of responsibility (Zille 2019:2). Besides a clear distinction between state and the ruling political party, the success of democracy is based on the principle of accountability. But accountability and responsibility does not reside in worshipping the person of a political leader or president, but in the basic values and virtuous that form the basis of constitutional democracy as, for example, pointed out by Plato. The implication is that the effectivity of the state should not be based on political favouritisms (public service run by cadre deployment), but by merit, virtue and accountability. It boils down to the following: The liberation ideal of democracy became disengaged from its moral basis. Liberation needs vehicles and people. It should never be cut off from a disposition of 'responsible respond-ability' directed by prudence, temperance, courage and justice.

At the end of her speech, Zille made an appeal to President Ramaphosa to link the dream of a democratic South Africa to the judicial framework of a constitutional democracy, in order to turn the current democratic turmoil into a more judicial ethical-based democracy.

\section{Cyril Ramaphosa: 'Cooperative democracy' and the dream of a unifying, prosperous and 'smart common-wealth' - The obstacle of delusive populism}

In an interview with Time (Baker 2019:41), Cyril Ramaphosa gave a very clear indication that his understanding of democratic processes in South Africa will be linked to the virtues of integrity and trustworthiness. This is in order to curb the previous culture of populist corruption, cadre deployment and the destructive threat of 'state capture', and therefore the important role of the Integrity Commission to address all forms of fraud and mismanagement.
Developmental democracy should be built on the legacy of Mandela, because South Africa must emerge out of widespread poverty (Ramaphosa in Baker 2019:40). ‘We will use the Mandela magic of finding solutions so that everybody feel that they are winning' (in Baker 2019:41).

To sum up the legacy of Mandela: An attempt to link democracy with a society free from all forms of discrimination. This is done by means of the bloodless revolution of cooperative negotiation; to establish an ethos of inclusivity and equality; and to safeguard the principle of 'justice for all'. This is thus the reason why Ramaphosa is frequently using inclusive language like 'everybody', 'together' and 'for all'.

The theme of the State of the Nation Address (SONA) on 20 June 2019 was the following: 'Let's grow South Africa together as we celebrate 25 years of freedom.' An important undergirding theme was the notion of cooperation, working together, inclusiveness, sense of belongingness and the emphasis on 'for all South Africans'. 'Working together, we have laid a firm foundation on which we can build a country in which all may know peace and comfort and contentment' (Ramaphosa 2019b:n.p.).

Within the framework of social consolidation, spatial integration and social cohesion, the emphasis was on unification within the confines of a prosperous 'commonwealth'2 for all people:

Let us agree, as a nation and as a people united in our aspirations, that within the next 10 years we will have made progress in tackling poverty, inequality and unemployment. (Ramaphosa 2019b:n.p.)

He made it very clear that democracy should promote a sense of cooperative unification, in order to establish a kind of harmony despite diversity and huge schisms in the South African society:

As South Africa enters the next 25 years of democracy, and in pursuit of the objectives of the NDP, let us proclaim a bold and ambitious goal, a unifying purpose, to which we dedicate all our resources and energies. (Ramaphosa 2019b:n.p.) ${ }^{3}$

It was furthermore argued that operative goals should be merged with education and skills-development. The president realised that skills development, education and economic development (the creation of a developmental state) should be morally and ethically based: 'We are committed to building an ethical state in which there is no place for corruption, patronage, rent-seeking and plundering

2.The spelling of 'common-wealth' is an indication that Ramaphosa wants to combine his sense of unifying togetherness (sense of belongingness) to economic targets that will address the predicament of poverty within the coming 10 years.

3.With reference to deploy an inclusive understanding of democracy, see the following directives: Let us agree, as a nation and as a people united in our aspirations, that within the next 10 years we will have made progress in tackling poverty, inequality within the next 10 years we will have made progress in tackling poverty, inequality and unemployment, where: - No person in South Africa will go hungry. - Ou economy will grow at a much faster rate than our population. - Two million mor young people will be in employment. - Our schools will have better educationa outcomes and every 10 -year-old will be able to read for meaning. - Violent crime will be halved. Let us make these commitments now - to ourselves and to each other - knowing that they will stretch our resources and capabilities, but understanding that if we achieve these five goals, we will have fundamentally transformed our society. 
of public money' - Ramaphosa 2019b). What desperately is needed, is a new social compact. In order to develop the country's human potential, huge emphasis should be place on the fostering of sound values to enhance a sense of integrative responsibility. 'We need to forge durable partnerships between government, business, labour, communities and civil society. This places a responsibility on each of us and all of us' (Ramaphosa 2019b:n.p.).

In his speech, he became quite philosophical in terms of the potential of a cooperative democracy that should be steered by creativity and imagination. He even became 'idea-matic' in terms of projecting a future with bright technological developments. 'I dream of a South Africa where the first entirely new city built in the democratic era rises, with skyscrapers, schools, universities, hospitals and factories' (Ramaphosa 2019b:n.p.). His dream was designed in such a way that it becomes a vital constituent of an inclusive democracy. 'This is a dream we can all share and participate in building' (Ramaphosa 2019b:n.p.). In his imagination, he sees a 'smart city'; thus, the challenge to be bold and reach beyond ourselves and do what may seem impossible!

After his state address (SONA), Ramaphosa was heavily criticised for his ideals and dreams. The more populist Economic Freedom Fighters (EFF), with leader Julius Malema at the front, most cuttingly posed the rhetorical question: 'What did Madiba see in you that we can't see?':

As the SONA debate kicked off, it was clear that Ramaphosa was in for some highly sceptical responses from the opposition which accused the President of delivering a dreamer's SONA, much too low on the implementation details required to turn fantasy into reality. (SONA Debate 2019)

The reaction in a nutshell: 'Stop dreaming, take a decision, wake up!' (SONA Debate 2019).

From a pragmatic point of view, the reaction is quite understandable. However, cooperative democracy needs vision, a kind of constructive life view and 'ideology'. In his book Ideology and Utopia, Karl Manheim (1966:49) points out that social engagement cannot take place without planning, goal setting and paradigmatic conceptualisation; wild action can easily lead to destruction.

It is true - ideology can indeed steers away from concrete action. It can easily be understood as distortion of reality and an expression of a kind of scepticism. This is thus the reason why people are sceptical of ideas and representations as applied by systems of thinking. Dreaming an idea can be regarded as more or less conscious disguises of the real nature of a situation. However, there is another conception of ideology, which can be differentiated from lies and distortions, namely a more inclusive, comprehensive conception of ideology: ideologies as the characteristics and composition of the total structure of the mind and vehicles for constructive change (Manheim 1966:50).

In fact, Plato was very clear about a philosophical stance and the value of dreams and ideas within the public arena of the state and processes of democratisation. For Plato (1946:171-172), the realm of ideals is the 'real world'. Therefore, the ideal has an indispensable value for practice in that thought thereby gives to action its right aim. For Plato, the human being, following his or her dream, is not a 'sleeping partner'. 'He is very much awake' (Plato 1946:179).

Despite the challenge to dream and to project a prosperous future, democracy is not a final guarantee. Within the history of humankind, the outcome of democratic transformation can become catastrophic indeed. Thus, the following warning by Leo Tolstoy (1978:vi) in his novel War and peace: The strive for societal equilibrium and justice (peace) can draw humankind into war and destruction; it demarcates the tension between evil and goodness, between the falsity of power abuse and the spirit of simplicity. 'In 1812 simplicity, goodness, and truth overcome power, which ignored simplicity and was rooted in evil and falsity' (Tolstoy 1978:vi).

Despite the notions of 'constitutional democracy' (Zille), and 'cooperative, unifying democracy' (Ramaphosa), the fact of disillusionment as well as Plato's scepticism regarding the hampering factor of the 'democratic type', the following question should be addressed: What is the 'missing link' in all the philosophical and ideological designs for a political understanding of democracy?

My basic hunch is that the virtues of prudence, temperance, courage and justice within the framework of gentleness (Plato), simplicity (Tolstoy) should be supplemented by the spiritual notion of compassion. Gratuitous compassion is the missing link in liberal democracy. Without compassion, virtues and ideological programmes run the danger of becoming prescriptive agendas and rigid formulas.

The gap between virtues and the transformation of life (within the dynamics of fostering a kind of empathetic process of democratisation) resides most of times in the void space of stigma and suspicion towards the other. Instead of becoming our 'comrade', 'friend' or 'companion' in the striving towards a compassionate, democratic society, the other can become our obstacle, our enemy, our opponent and adversary.

E. Goffman (1990:11-12) links the establishment of stigma to social settings of prejudice. Stigma is therefore a kind of applied, skewed social identity. It develops within the routines of social intercourse in established settings. The problem is then that first appearances enable social scepticism to anticipate 'social identity'. Due to skewed perceptions and prejudice, we easily transform these anticipations into normative expectations and presented demands. According to Goffman (1990:11-12), the demands we make 'in effect' and the character we impute to a person can be seen as an imputation made in potential retrospect; ' ... a characterization "in effect," a virtual social identity'. When this identity is assessed as negative, bad, dangerous, weak or even sinful, 
we reduce the difference to wrong or evil. In our mind, we reduce the person (the foreign other) to a tainted, discounted individual.

Within the current debate in South Africa regarding a kind of neo-racism and the escalating polarisation between 'the smugness of colonial white people' and the 'arrogance of land-demanding deprived Azanians', skewed attributes become a stigma, especially when its discrediting effect is very extensive. Sometimes it is called a failing, a shortcoming, a handicap. Fixed stigmata therefore constitute a special discrepancy between virtual and actual social identity, so that labelled people are pushed to the edge of society. They become privileged colonial intruders or social disadvantaged outsiders without hope.

The eventual problem with social and political stigmata, political prejudices are that they infiltrate the realm of disposition so that the process of democratisation become stuck and cannot deliver the goods. What is most needed is therefore a transformation of the heart: radical attitudinal changes.

The bridge between virtue and a practice of democratic transformation resides, to my mind, in the character and quality of disposition and attitude (a humane habitus). It is in this respect that the Christian understanding of compassion as a poignant description of the attitude of Christ (phronesis - Phlp 2:5) comes into play.

When the other is disillusioned and impoverished, one should take the following warning of Archbishop Desmond Tutu (2004) seriously:

We were involved in the struggle because we believed we would evolve a new kind of society. A caring compassionate society. Now many, too many, of our people live in gruelling demeaning, dehumanising poverty. We are sitting on a powder keg. We really must work like mad to eradicate poverty. (p. 33)

This emphasise thus the importance of the question: What is the contribution of a Christian ethos and a spiritual interpretation to the telic dimension of life and a comprehensive understanding of our being human (the anthropological question)?

\section{Jesus Christ: 'The compassionate type' - The idol of a 'God without a heart' (positivistic Christianity)}

The plea of Desmond Tutu is an appeal to the church to become involved in current attempts to restore democracy and supply a moral basis for further processes of transformation. President Cyril Ramaphosa is very clear that he wants to address the notion of 'zero accountability', corruption and abuse of power (Daily Maverick 2019). According to the president, what is most needed is a change in attitude and a new moral basis for societal transformation.
In article by S. van der Walt (2019:2), it is emphasised that the euphoria about Ramaphosa's first 100 days is over. He acknowledged that the 'Ramaforie' is over (Van der Walt 2019:2). In his Newsletter from the Desk of the President, he points out that there is a huge loss of trust and confidence regarding the ability of government to contribute to fundamental and radical change. Credibility and integrity should be restored (Van der Walt 2019:2). In order to restore institutional trust, he made an appeal to all institutions to cooperate and to restore a moral basis: Collectively we all have a communal task to restore credibility and to root out all forms of corruption (Van der Walt 2019:2). What is the contribution of Christian communities of faith in this regard?

It was already mentioned that the contribution of practical theology and pastoral caregiving resides in the realm of habitudinal change, in order to contribute to 'worldly transformation' (Fairley 1983:39). The argument is that churches and ministerial practice (Schleiermacher 1980) should understand the impact of what can be called an 'ecclesial presence' within the happenstance of daily living. According to Fairley (1983:39), this presence can be 'redemptively pervasive' of any and all social, political and cultural spaces without becoming identical with any of them and developing official and timeless ecclesial-political institutions.

One can call this ecclesial presence in social contexts fides quaerens societatum (Cilliers 2012:67). Practical theology could then also be viewed as a source of hope (fides quaerens spem) (Louw 2016:78). But it should then discover one of the most basic features of what can be called the 'human soul', namely the dimension of the human heart as expressed in disposition and attitude as directed by the principle of wisdom. This is the same principle that Plato rendered as the source for a credible democratic stance within the Athenian politics of civil society.

I was utterly surprised to discover in Feuerbach's book on the essence of the Christian faith, Das Wesen des Christentums (1904), his plea and struggle to free traditional and therefore 'orthodox theology' from its God-ideology in order to turn theological reflection to the praxis issues of life (Schleiermacher 1980); to the meaning of our being human within social contexts and daily exposure to unexpected tragedy. He (Feuerbach 1904:283) called this focal point the well-being (heil) of humans. His intension was to challenge Christian faith and theology to bring hope to human beings and heal the pain of a human soul within the transience of life. Faith should deal with our human exposure to anguish and hopelessness. Christians should therefore be agents of hope. Feuerbach's intention (1904:127) was actually to rediscover that the Christian God is a God with a heart full of passion; the God of pure passion; the God of pure suffering (die Passion pura, das reine Leiden). A God without passion and compassion is an idol.

One can therefore make a very bold statement and say that the passio Dei could be rendered as the essence of a Christian view 
on life. In fact, the passio Dei, in its connection to the praxis of God, redefines 'practice' in theology and the whole of Christian piety to compassion ( $\mathrm{rhm}$ in close connection to the root $h n n$, which means to be gracious) (Louw 2016:273-380). ${ }^{4}$

In the Synoptic gospels, pascho is used within the framework of the passion of Christ. Compassion in a Christian understanding of a theology of compassion is essentially determined by Christ's vicarious suffering (Gärtner 1978:724). Compassion described substitution and exchange. Thus, the reference to Christ's vicarious suffering which took place ephapax [once for all] (Heb 7:27). Our sympathy and compassion are determined by the fact that Christ exercises compassion (Gärtner 1978:722).

Compassion is furthermore an indication of the quality of the Christian faith enfleshed in humane interaction, communication and disposition (habitus). It should therefore not be understood in isolation from the dynamics of relationships within social contexts. Hēesèd refers to Israel's assurance of God's unfailing benevolence that should be exercised as a mode of loving-kindness, which is 'active, social and enduring' (Davies 2001:243).

The impression could be that compassion reduces the Christian faith to sheer emotion and the dimension of the affective. However, instead of the emotional interpretation of compassion by the Stoics and their emphasis on the fact that passion (pathe ) should be overcome in order that the ideal of 'dispassionateness' (apatheia) may be attained, a Christian understanding of compassion described the essential function of being a Christian (a Christian anthropology). Compassion, in close connection with sympathy and comfort, describes an active and practical compassion (sympaschō). As an appropriate indication of a vivid faith in Christ (1 Cor 12:26; Heb. 10:34), compassion encompasses the whole of Christian ministry (Gärtner 1978:724). In this regard, compassion should be connected to a ministry of serving (diakoneō) (Gärtner 1978:724).

Passion and compassion as enfleshment and exhibition of the passio Dei are about the essence of all Christian confessions; it constitutes a theology of caregiving as directed by the theological directives of splanchna, hēsēd, rhm, oiktirmos and paschō. As theological categories, constituting the paradigmatic framework of the Christion witness (marturia), compassion witnesses the lament of God as expressed in the derelictio-cry of the suffering Servant at the cross. One can even say that together with oiktirmos and hesesed, the comfort of compassion expresses the being quality of God as connected to human vulnerability and suffering (Esser 1976:598).

The verb splanchnizomai is used in the gospel to make the unbounded mercy of God visible. This is the reason why in the parable of the Good Samaritan (Lk 10:33), splanchnizomai

4. With reference to Vincent Brummer (2006.299-302) on can say that the passio....

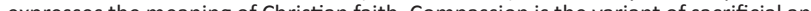
expresses the meaning of Christian faith. Compassion is the variant of sacrificial and divine love. It is an indication of the concrete praxis hermeneutics of the amicitic Dei). 'It is only by loving God that we can achieve ultimate happiness and complete fulfilment in our lives' (Brümmer 2006:299). expresses the attitude of complete willingness to use all means, time, strength and life for saving at the crucial moment (Esser 1976:600). One can therefore conclude and say that compassion indicates the true character of a Christian disposition, attitude and mode of living; it represents the whole of the presence of God within every sphere of life.

The advantage of a theology and ministry of compassion is that, instead of the traditional attempt in church doctrine to capture the essence of God in systematic and rational categories (our reasonable faith - most of times causative positivistic categories), the essence of Christianity is now described in terms of 'bowel categories'. Mercy and pity refer to the whole being of a human being; the whole of human existence is becoming a kind of intestinal contraction - the movement of the heart as expression of sapientia. Splanchna is connected to the verb splanchneuō, meaning 'eat the entrails, prophesy from the entrails' (Esser 1976:599).

Comfort displays the mercy ( $h \bar{e} s \bar{e} d$ ) of a living God within a covenantal encounter with human beings. In the New Testament the mercy of God is often described in bowel categories, namely ta splanchna (splanchnizomai [movement and pain within the bowels]). ${ }^{5}$ A good example of comfort, as linked to a theology of the intestines, is Luke 15:20. When the father saw his prodigal son, he was moved with pity and tenderness. Ta splanchna displays the unconditional love and mercy of a caring Father; it is essentially a component of the Father's being functions. Ta splanchna reveals God as a Presence; 'a Companion, “your God"' (Hall 1993:147). It also shapes Christian anthropology as an anthropology of compassionate being-with; Christian humanism enfleshed in attitudes of care and diaconic outreach to people in need. Christian anthropology is then demarcated by not in the first place an ethos of achievement, but by a sacrificial ethos of diaconic serving.

Compassion can be described as both an expression of a praxis of wisdom as well as unifying social phenomenon regarding the fostering of a culture of human dignity. Compassion thus creates a bond of human society and displays human dignity. 'Humanitas is to be displayed to those who are "suitable" and "unsuitable" alike, and "this is done humanely (humane) when it is done without hope on reward"' (Lactantius in Davies 2001:35).

\section{Conclusion}

The 'compassionate type' is in the first place about exchange and replacement, that is, to think, understand and feel from the viewpoint of the other. For this exchange, the wisdom of the heart (feeling-with the other) is imperative. Instead of becoming a victim due to disillusionment and disappointment, compassionate being-with is about proactive exchange and understanding.

5.It is my contention that the passio dei is an exposition of the praxis concept of to splanchna. The latter is the passio de is anrew root rhm [to have compassion]. It is splanchna. The latteris related to the Hebrexp root rhm [to have compassion]. It is used in close connection to the root $h n n$, which means to be gracious. Together with oiktirmos and hesed it expresses the being quality of God as connected to human vulnerability and suffering. The verb splanchnizomai is used to make the unbounded mercy of God visible (Esser 1976:598). 
The 'compassionate type' focuses on the other within the encounter with people suffering from stigmatisation, discrimination and rejection. The compassionate type starts where the other is (a grassroots approach instead of a topdown approach); it reaches out to the other with diakonic concern. In terms of Levinas (1972), one should rather reach out to all the Others or others that reside in the footprint of 'illeity' ${ }^{\prime}$. The challenge in compassionate reaching out and creating a sense of communal fellowship, is to understand the social-ethical entanglements of fellow human beings. One should understand them from the perspective of the one-for-the-other (l'un pour l'autre) (Levinas 1972). One thus needs to be there where they are. For this exchange of positions, divine passion and the ethos of sacrificial beingwith are vital. Compassion inhabits enfleshes an understanding of the heart (sapientia) that penetrates the stigma of dehumanising suspicion and hateful enmity.

To sum up: The 'democratic type' should be shaped by the aptitude or attitude (habitus) of the 'compassionate type':

- 'The compassionate type' operates in terms of sacrificial ethics and not in the first place from the basis of an individualised achievement ethics. It operates according to the ratio of diakonic sharing rather than economic advantage and profit.

- The disposition of 'the compassionate type' is shaped by the 'bowel categories' of pity rather than the 'pleasure categories' of selfish need-satisfaction, wealth, importance and affluence.

- The virtues of 'the compassionate type' implies more than merely prudence, temperance, modesty and justice. Disposition and habitus are shaped by gratuitous virtues - fruit of the Spirit: unconditional love; celebrating joy; reconciliatory peace; enduring patience; gracious kindness; integrative, inclusive goodness; courageous faithfulness; the simplicity of gentleness and the pain of self-controlling outreach (see Gl 20:22-14).

- The theological directives of splanchna, heeseed, rḥm, oiktirmos and pascho function in the Bible within the ethical framework of justice and trustworthiness. Its aim is to care for the suppressed, the hungry, and the poor and stigmatised strangers. Deuteronomy 10:18: 'He defends the cause of the fatherless and the widow, and loves the foreigner residing among you, giving them food and clothing.' This is what is meant by 'a compassionate democracy' in terms of Hebrew and Christian spirituality.

The 'democratic type' should be steered and directed by 'the compassionate type'. Disillusionment within processes of democratisation is unavoidable and should be viewed as an ingredient of a praxis of social and political transformation. The directives of freedom, human rights and equality are not enough for democratic sustainability. They should be supplemented by the habitus of compassion, in order to probe the heart and needs of the opposing other and attitude of the disillusioned protagonist. The well-being in a

6.11 e is the Latin form for the third person ilie is a form of addressing the presence. transcendence by means of traces, because God is transcendent, already ahead,
and only leaves traces. Illeity refers to transcendence as presencing: He is there. He and only leaves traces. Illeity refers to transcendence as presencing: He is there unified commonwealth and an institutional democracy is fundamentally dependent on the benevolence, goodwill, friendliness, graciousness and obligingness of compassionate co-responsibility and sharing coexistence. Democratisation should opt for peaceful coexistence rather than patronising assimilation.

\section{Acknowledgements Competing interests}

The author declares that no competing interest exist.

\section{Author's contributions}

I declare that I am the sole author of this research article.

\section{Ethical consideration}

This article followed all ethical standards for carrying out research without direct contact with human or animal subjects.

\section{Funding information}

This research received no specific grant from any funding agency in the public, commercial, or not-for-profit sectors.

\section{Data availability statement}

Data sharing is not applicable to this article.

\section{Disclaimer}

The views and opinions expressed in this article are those of the author and do not necessarily reflect the official policy or position of any affiliated agency of the author.

\section{References}

Abramson, A., Berenson, T. \& Walcott, J., 2019, 'What does a terrorist look like?', Time, 19 August, pp. 20-23.

Baker, A., 2019, 'South Africa's dividing line', Time, 13 May, pp. 34-41.

Ball, M., 2018, 'Nation divided', Time, 19 November, pp. 20-30.

Bauman, Z., 2016, 'Nationalismusistein Ersatz: Spiegel-Gespräch', Der Spiegel 36(3.9), 122-125.

Bremmer, I., 2019a, 'Selling democracy', Time, 27 May, pp. 17-18.

Bremmer, I., 2019b, 'World identity crisis', Time, 07 October, pp. 29-33.

Brown, D., 2017, Happy: Why more or less everything is fine, Corgi Books, London.

Brown, T., 2019, 'Anarchy in the U.K.', Time, 17 June, p. 34

Brümmer, V., 2006, Brümmer on meaning and the Christian faith, Ashgate, Aldershot.

Cilliers, J., 2012, Dancing with deity: Re-imaging the beauty of worship, Bible Media, Wellington.

Coe, J., 2019, 'How Brexit broke Britain', Time, 17 June, pp. 31-33.

Corruption Watch, 2018, 'Week sixth overview', 01 October 2018, viewed 08 October 2019, from https://www.corruptionwatch.org.za/zondo-commissionOctober 2019, from https://www.corruptionwatch.org.za/zondo-commission-
week-6-overview/?gclid=EAlalQobChMI3L620 KM5QIViE8YCh3r6A5qEAAYASA AEgL8n_D_BwE

Daily Maverick, 2019, 'A determined president hampered by the Quagmire of State Capture', 07 October, viewed 08 October 2019 from https://www.dailymaverick. co.za/article/2019-10-07-cyril-ramaphosa-a-determined-president-hamperedby-the-quagmire-of-state-capture/

Davies, O., 2001, A theology of compassion: Metaphysics of difference and the renewa of tradition, William B. Eerdmans Publishing Company, Grand Rapids, MI.

Dolph, B.H., 2019, 'Not buying it', Time, 24 June, p. 2.

Esser, H.-H., 1976, 'Splanchna', in C. Brown (ed.), Dictionary of New Testament theology, vol. 2, pp. 598-601, Paternoster Press, Exeter. 
Fairley, E., 1983, 'Theology and practice outside the clerical paradigm', in D.S.Browning (ed.), Practical Theology, pp. 21-41, Harper \& Row, San Francisco.

Feuerbach, L., 1904, Das Wesen des Christentums, Verlag Philipp Reclam, Leipzig.

Gärtner, B., 1978, 'Suffer (paschō)', in C. Brown (ed.), Dictionary of New Testamen theology, vol. 3, pp. 719-725, Paternoster Press, Exeter.

Goffman, E., 1990, Stigma. Notes on the management of spoiled identity, PrenticeHall, Penguin Books, Englewood Cliffs.

Gouws, A., 2019, 'Protes ál meer en ál intenser', Die Burger, 08 Oktober 2019, p. 10.

Hall, D.J., 1993, Professing the faith: Christian theology in a North American context, Fortress Press, Minneapolis, MN.

Harari, Y.N., 2016, Homo Deus: A brief history of tomorrow, Harvill Secker, London.

Levinas, E., 1972, Humanisme de L'autre Homme, Fata Morgana, Montpellier.

Louw, D.J., 2016, Wholeness in hope care: On nurturing the beauty of the human soul in spiritual healing, Lit Verlag, Wien.

Manheim, K., 1966, Ideology and Utopia, Routledge \& Kegan Paul Ltd., London.

Piechowiak, M., 2019, Plato's conception of justice and the question of human dignity, Peter Lang, Berlin.

Plato, 1946, The Republic of Plato, transl. F.M. Cornford, Clarendon Press, Oxford.

Plato, 2015, The failure of democracy, viewed 16 May 2015, from http://faculty. frostburg.edu/phil/forum/PlatoRep.htm

Ramaphosa, C., 2018, 'Black anger about "Lackadaisical" whites with power', viewed 09 October 2019, from https://www.fin24.com/Economy/ramaphosa-growingblack-anger-about-lackadaisical-whites-with-power-20181213
Ramaphosa, C., 2019a, Attitude change for roads, October, viewed 09 October 2019, from https://www.pressreader.com/south-africa/the-witness/20191006/ 281698321493690

Ramaphosa, C., 2019b, State on the nation address, viewed 27 June 2019, from https://mg.co.za/article/2019-06-20-read-it-in-full-ramaphosas-state-of-thenation-address

Rushdie, S., 2019, Quichotte, Jonathan Cape, London

Schleiermacher, F.D.E., 1980, Der Christliche Glaube nach der Grundsätzen der evangelischen Kirche im Zusammenhänge dargestellt (1821/22), Teilband 1 Walter de Gruyter, Berlin.

Singer, P., 2015, The most good you can do: How effective altruism is changing ideas about living ethically, Yale University Press, New Haven, CT.

SONA Debate, 2019, viewed 28 June 2019, from https://www.dailymaverick.co.za/ article/2019-06-25-malema-to-ramaphosa-stop-dreaming-ta

Taleb, N.N., 2013, Antifragile: Things that gain from disorder, Penguin Books, London. Tolstoy, L., 1978, War and peace, Penguin Books, Harmondsworth.

Tutu, D., 2004, Nelson Mandela annual lecture, viewed 20 September 2014, from https://www.nelsonmandela.org/content/page/annual-lecture-2004

Van der Walt, S., 2019, 'Ja, Ramaforie is oor', Die Burger, 01 Oktober, p. 2.

Vick, K., 2019, “It's a dark period": The Stanford expert known as "Mr. Democracy" on the shrinking free world', Time, 13 June, p. 52.

Zille, H., 2019, 'Remarks at the FW de Klerk Mini Conference on the South African Constitution: Quo Vadis?', 06 June, pp 1-6, viewed 28 July 2019, from file:///c:/ users/djl/documents/hermien/190606_fwdk_speech_helen_zille.pdf 